\title{
EFFECT OF MECHANICAL AGITATION ON HYBRIDOMA CELL GROWTH
}

\author{
Gyun Min Lee ${ }^{1}$, Thomas K. Huard ${ }^{2}$, Mark S. Kaminski ${ }^{2}$ and Bernhard O. Palsson ${ }^{1 *}$ \\ ${ }^{1}$ Department of Chemical Engineering and ${ }^{2}$ Department of Internal Medicine \\ University of Michigan, Ann Arbor, MI 48109
}

\begin{abstract}
Hybridoma cells ( $\mathrm{S} 3 \mathrm{H} 5 / \gamma 2 \mathrm{bA} 2$ ) were grown in spinner flasks at different agitation speeds. It was found that cells in stationary and decline phases of growth were sensitive to shear force caused by agitation but cells in growth phase seemed less sensitive to the shear forces introduced. The death rate was found to be $0.007 \mathrm{hr}^{-1}$ in T flasks but $0.018 \mathrm{hr}^{-1}$ and 0.028 $\mathrm{hr}^{-1}$ at 100 and $200 \mathrm{rpm}$, respectively, while the growth rate was about $0.05 \mathrm{hr}^{-1}$ for all cases.
\end{abstract}

\section{INTRODUCTION}

In vitro cultivation of hybridoma cells is a common means for the production of monoclonal antibody (MAb). It has been frequently noted that hybridoma cells secrete MAb throughout batch growth and a significant portion of MAb is produced during stationary and decline phases (Birch et al., 1983; Velez et al., 1986; Brennan et al., 1988). This production does not seem to be due to the release of antibody from dying cells but due to active secretion from viable cells throughout the growth cycle (Renard et al., 1988; Walker et al., 1988). Usually hybridoma cells die rapidly after reaching maximum cell density and it is, therefore, important to maintain cell viability during the stationary and decline phases. Numerous studies have been carried out to achieve this goal, especially by adding nutrients and removing waste products (Luan et al, 1987; Dodge et al., 1987; Lindberg et al., 1988). Though many studies deal with the effect of shear forces on animal cells, the importance of shear effect on cells in stationary and decline phases of growth has gone unnoticed (e.g., de St. Groth, 1983; Dodge et al., 1986). Here, we have investigated the effect of shear caused by agitation in spinner flasks on the maintenance of cell viability during stationary and decline phases. Cell growth in $\mathbf{T}$ flask was used as a reference. Furthermore, the MAb production, nutrient uptake and waste product formation were measured at the different agitation speeds.

\section{MATERIALS AND METHODS}

Cell line, medium and culture maintenance The murine hybridoma used was $\mathrm{S} 3 \mathrm{H} 5 / \gamma 2 \mathrm{bA} 2$. The antibody produced by this cell line is of the $\gamma 2 \mathrm{~b}$ isotype, and the specificity of the antibody is against the anti-idiotype on the surface of the 38C13 lymphoma (Kaminski et al., 1987).

The cell culture medium was RPMI 1640 (Sigma, St.Louis, MO) supplemented with $10 \%$ fetal bovine serum (Gibco Laboratories, Grand Island, NY) and $100 \mathrm{units} / \mathrm{ml}$ of each penicillin and of streptomycin (Sigma). The cells were maintained in $\mathrm{T} 25 \mathrm{~cm}^{2}$ plastic cell cuture flasks (Bellco Glass, Inc., Vineland, $\mathrm{NJ}$ ) at $37^{\circ} \mathrm{C}$ in a humidified $\mathrm{CO}_{2}$ incubator. The cells were diluted 1:4 with fresh medium every other day.

Cell cultures Exponentially growing cells were inoculated into $25 \mathrm{~cm}^{2} \mathrm{~T}$ flasks and spinner flasks (Bellco) at the initial density of $10^{5} \mathrm{cells} / \mathrm{ml}$. The total working volumes of $\mathrm{T}$ flasks and spinner flasks were $10 \mathrm{ml}$ and $50 \mathrm{ml}$, respectively. Ten T flasks were inoculated and one flask was taken each time for assays. Two sets of experiments were performed using spinner flasks. For the first set, cell cultures were carried out at different agitation speeds (100 and $200 \mathrm{rpm}$ ). The second set of experiments were performed as follows: at first, cells were grown in 8 spinner flasks at $150 \mathrm{rpm}$. After $60 \mathrm{hr}$ cultivation, the cell culture suspension was collected and mixed well. Then, $10 \mathrm{ml}$ of cell suspension were added to each T flask and $50 \mathrm{ml}$ of cell suspension were added to each spinner flask which was placed on the magnetic stirrer (Bellco) with different agitation speeds. All the experiments were performed in a humidified $\mathrm{CO}_{2}$ incubator. 
Analytical methods Cell growth was monitored by counting viable cells with a hemocytometer. The viable cell population was distinguished from dead cells by the trypan blue dye exclusion. The cell culture suspension was centrifuged and the supernatant was aliquoted and kept frozen at $-80^{\circ} \mathrm{C}$. Glucose and lactate were measured enzymatically using Sigma diagnostic kits (No.315 and No.826-UV); ammonia was measured using ammonia electrode (Orion Research Inc., Model 95-12).

The antibody, $\gamma 2 \mathrm{~b}$, was quantified using an enzyme linked immunosorbent assay (ELISA). Anti-mouse IgG (Sigma) was used to coat wells of plates at a concentration of $10 \mu \mathrm{g} / \mathrm{ml}$ of PBS overnight at $4^{\circ} \mathrm{C}$ and the wells were blocked with PBS-1\%BSA for $1 \mathrm{hr}$. After these plates were washed 4 times, various dilutions of triplicate samples with proper concentration of standard (purified MAb, S3H5/ 2 2bA2) were added to plates. After $45 \mathrm{~min}$ incubation at room temperature, plates were washed and alkaline phosphotase-labelled affinity purified goat antibody against mouse IgG2b (Southern Biotechnology Associates,Inc., Birmingham, AL) was added to plates. After $45 \mathrm{~min}$, the plates were washed and alkaline phosphotase substrate was added. The optical density at $410 \mathrm{~nm}$ of each well was recorded by ELISA reader (Molecular Devices, Palo Alto, CA).

\section{RESULTS AND DISCUSSION}

In many large scale suspension culture apparatus, mechanical agitation is necessary to ensure good heat and mass transfer. However, agitation should not be so vigorous that the fragile cell membranes are disrupted. Since it is important to maintain the cell viability for the production of $\mathrm{MAb}$, the effect of mechanical agitation on cell growth and viability was investigated. Cell cultures in $\mathrm{T}$ flasks were used as a reference for shear-free conditions.

As shown in Fig.1(a) \& (b), no significant differences in cell growth rate and cell viability in exponential growth phase were observed in all three cases tested. The viability in exponential growth was above $90 \%$ in all cases. However, the cell death rate and cell viability in decline phase of cell growth were very sensitve to agitation speed. Viable cell number and viabilty in case of $200 \mathrm{rpm}$ were reduced much faster than in $T$ flasks which means cells in decline phase are more shear sensitive than cells in exponential phase. The rapid decrease of cell viability at 200 $\mathrm{rpm}$ resulted in lower MAb concentration $(140 \mu \mathrm{g} / \mathrm{ml})$ than in T flasks $(250 \mu \mathrm{g} / \mathrm{ml})$. The decrease of viable cell number after reaching maximum density seems to follow first order kinetics with respect to viable cells (Fig.1(a)). The specific death rates were determined from the slope of the growth curve during decline phase, e.g. as in Fig.1(a). Specific growth rates in case of $100 \mathrm{rpm}$ and $200 \mathrm{rpm}, 0.051$ and $0.049 \mathrm{hr}^{-1}$, respectively, were comparable with that in T flasks, 0.052 $\mathrm{hr}^{-1}$. However, specific death rate in $200 \mathrm{rpm}\left(0.028 \mathrm{lir}^{-1}\right)$ was much higher than that $(0.007$ $\left.\mathrm{hr}^{-1}\right)$ in $\mathrm{T}$ flasks and at $100 \mathrm{rpm}\left(0.018 \mathrm{hr}^{-1}\right)$. The specific death rates and growth rates for the various conditions are summarized in Table 1 .

\begin{tabular}{|c|c|c|}
\hline \hline$r p m$ & specific growth rate, $h^{-1}$ & specific death rate, $\mathrm{hr}^{-1}$ \\
\hline 0 (T flask) & 0.052 & 0.007 \\
\hline 100 & 0.051 & 0.018 \\
\hline 200 & 0.049 & 0.028 \\
\hline
\end{tabular}

Table 1: Specific growth rate and specific death rate at different agitation speeds.

As shown in Fig.1(a) \& (c), hybridoma cells (53H5/ 2 2bA2) produce a significant amount of MAb during the decline phase. To confirm that MAb accumulation during the decline phase was due to active secretion of $\mathrm{MAb}$ from viable cells, MAb concentration versus the integral of viable cell count with respect to time was plotted (Luan et al., 1987; Renard et al., 1988). As can be seen in Fig.l(d), the relation was almost linear except ir the region of over $1.10^{8} \mathrm{cells} \cdot \mathrm{hr} / \mathrm{ml}$ in $T$ flasks where essential precursors for synthesizing MAb might be depleted. This supports the hypothesis that the viable cells in the decline phase of growth produce MAb at a constant rate as long as essential precursors for synthesizing MAb are present in the medium. The specific MAb production rate was about $1.6 \mathrm{pg} / \mathrm{cell} \cdot \mathrm{hr}$, as evaluated from the slope in Fig.1(d). 

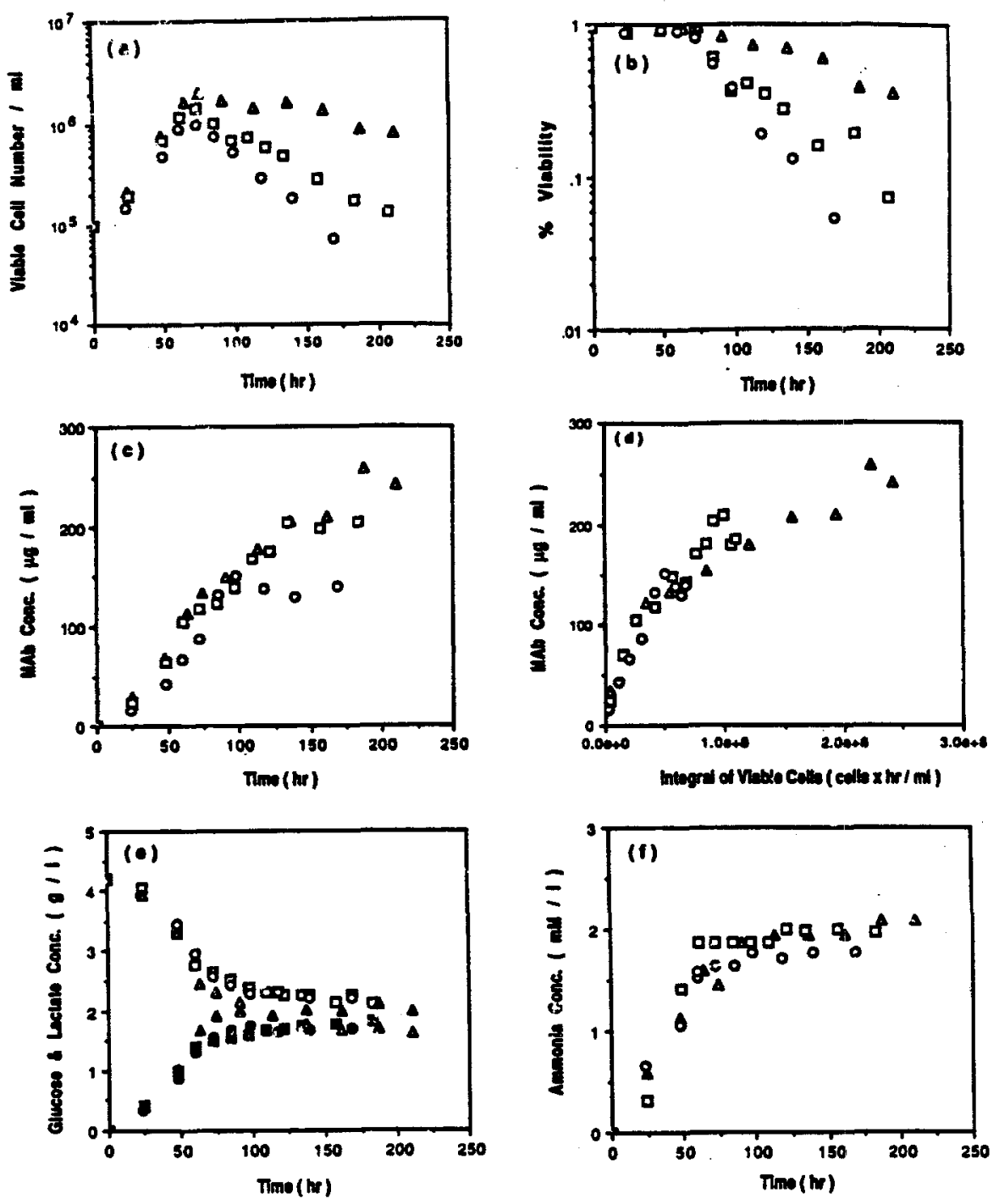

Figure 1: Cell growth in $\mathrm{T}$ flasks and spinner flasks at different agitation speeds : (a) cell growth curves; $₫$ Hask, $\rightarrow 100 \mathrm{rpm}, \multimap 200 \mathrm{rpm}$, (b) cell viability, (c) antibody concentration, (d) correlation between the integral of viable cells and MAb production, (e) open symbol, glucose concentration, closed symbol, lactate concentration and (f) ammonia concentration.

Since lactate and ammonia are believed to influence cell viability, we measured both lactate and ammonia concentrations (Lindberg et al., 1988). As shown in Fig.1(e) \& (f), lactate and ammonia concentrations were similar for the three cases and even slightly higher in $\mathrm{T}$ flasks. This observation indicates that the rapid decrease of viable cell number during agitation at $200 \mathrm{rpm}$ was not due to metabolic differences or the buildup of waste, but rather due to the differences in shear force. The final lactate and ammonia concentrations in $T$ flasks were $2.0 \mathrm{~g} / \mathrm{l}$ and $2 \mathrm{mM} / \mathrm{l}$, respectively, and the ratios of lactate produced to glucose consumed were in the range of 0.77 and $0.84 \mathrm{~g} / \mathrm{g}$ in three cases.

We excluded the hypothesis that the viability of cells during the decline phase could be influenced by the agitation speed during exponential growth. After cultivating cells at $150 \mathrm{rpm}$ for about $60 \mathrm{hrs}$, cells were cultivated at $100 \mathrm{rpm}$ and in T flasks. As shown in Fig.2(a), the cell death rate could be lowered by reducing the agitation speed. When cells were transferred to $\mathrm{T}$ flasks and cultivated, the cell death rate was $0.007 \mathrm{hr}^{-1}$ which was the same cell death rate as when cells were cultivated in $T$ flasks from the beginning (Table 1). MÁb concentration was also increased by prolonging cell viabilty. When agitation rates were lowered from $150 \mathrm{rpm}$ to static in T flasks and $100 \mathrm{rpm}, \mathrm{MAb}$ concentrations wcre increased from 169 to 190 and 220 $\mu \mathrm{g} / \mathrm{ml}$, respectively. There were no significant differeares in hartate and ammonia concentrations in three cases tested. 

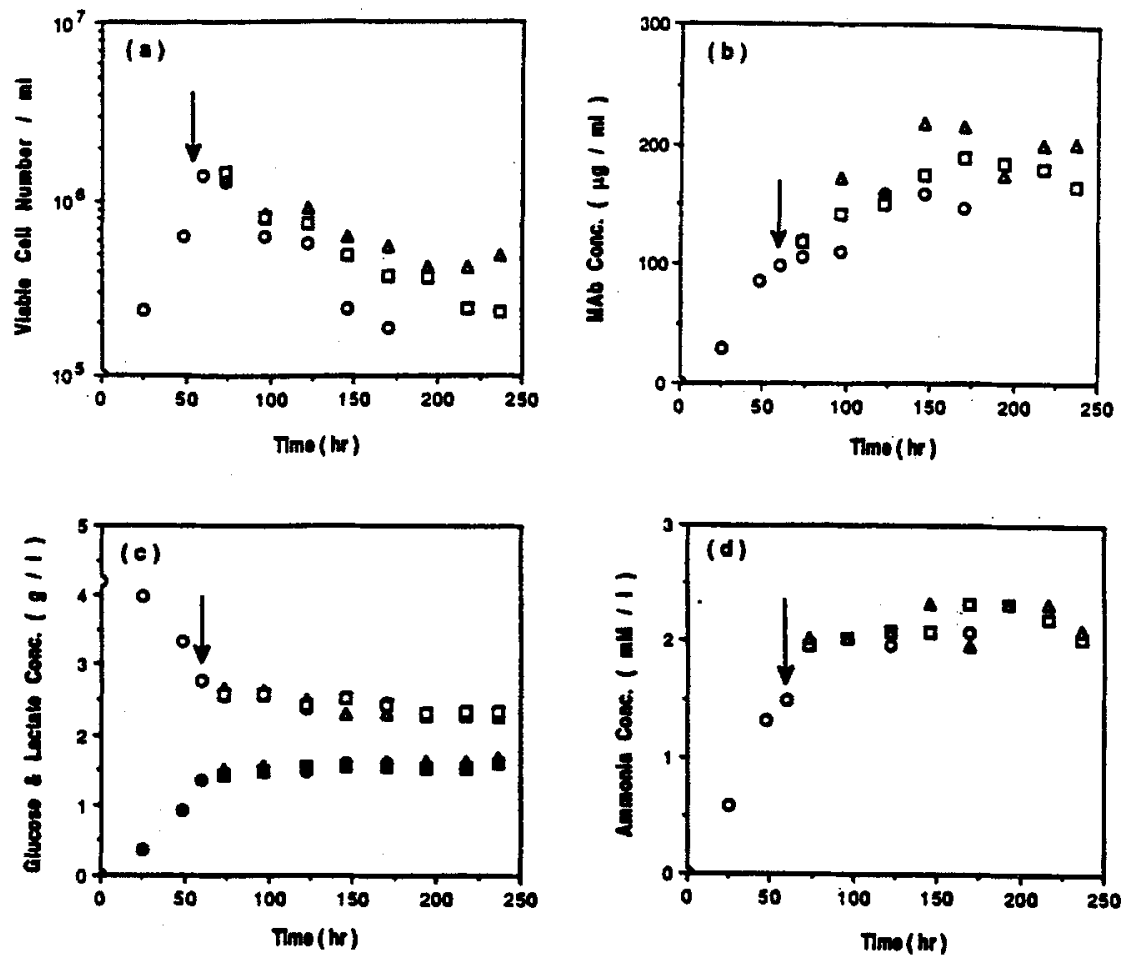

Figure 2: Shift of agitation from $150 \mathrm{rpm}$ to various agitation speeds : (a) cell growth curves; $T$ lasks, $100 \mathrm{rpm},-150 \mathrm{rpm},(\mathrm{b}) \mathrm{MAb}$ concentration, (c) glucose and lactate concentrations, (d) ammonis concentration

In conclusion, hybridoma cells ( $33 \mathrm{H} 5 / \gamma 2 \mathrm{bA2}$ ) produce a significant amount of MAb in the decline phase of growth by active secretion from viable cells. Therefore, it is important to maintain cell viability to increase the MAb production. Since cells in decline phase of growth appear to be very shear sensitive, severe agitation should be avoided in this phase of growth to achieve this goal.

\section{REFERENCES}

Brennan, A. J., Shevitz, J. and Macmillan, J. D. (1987) Biotechnology Techniques, 1, 169-174.

Boraston, R., Thompson, P. W., Garland, S., and Birch, J. R. (1983) Dev. Biol. Stand., 55, 103-111.

de St. Groth, F. (1983) J. Immonol. Methods, 57, 1.21-136.

Dodge, T. C. and Hu, W. S. (1986) Biotechnol. Lett., 8, 683-686.

Dodge, T. C., Ji, G. Y. and Hu, W. S. (1987) Enzyme Microb. Technol., 9, 607-611.

Kaminski, M. S., Kitamura, K., Maloney, D. G. and Levy, R. (1987) J. Immunol., 138, 1298-1296. Lindberg, G. and Ronning, O. (1988) Production of an Inhibitory Factor by hybridoma Cells

Grown InVitro. Abstract, Engineering Foundation Conference on Cell Culture

Engineering.

Luan, Y. T., Mutharasan, R. and Magee, W. E. (1987) Biotechnol. Lett., 8, 535-538.

Luan, Y. T., Mutharasan, R. and Magee, W. E. (1987) Biotechnol. Lett., 11, 751-756.

Renard, J. M., Spagnoli, R., Mazier, C., Salles, M. F. and Mandine, E. (1988) Biotechnol. Lett., 10, 91-96.

Velez, D., Reuveny, S., Miller, L. and Macmillan, J. D. (1986) J. Immunol. Methods, 86, 45-52.

Walker, A. G., Davison, W. and Lambe C.A. (1987) Proc. $4^{\text {th }}$ European Congress on Biotechnology, $3,587$.

\section{ACKNOWLEDGEMENT}

The authors thank Ms. Christina Liu for useful discussions and technical assistance. This work was supported by National Science Foundation (FET-8712756). 